\title{
Vascular safety of erenumab for migraine prevention
}

David Kudrow, MD, Julio Pascual, MD, PhD, Paul K. Winner, DO, David W. Dodick, MD, Stewart J. Tepper, MD, Uwe Reuter, MD, Frank Hong, MD, PhD, Jan Klatt, MD, Feng Zhang, MS, Sunfa Cheng, MD, Hernan Picard, MD, PhD, Osa Eisele, MD, MPH, Julie Wang, DPM, Jonathan N. Latham, PharmD, and Daniel D. Mikol, MD, PhD

Neurology ${ }^{\circledR}$ 2020;94:e497-e510. doi:10.1212/WNL.0000000000008743

\section{Abstract \\ Objective}

To examine the cardiovascular, cerebrovascular, and peripheral vascular safety of erenumab across migraine prevention studies.

\section{Methods}

Vascular adverse events (AEs) and blood pressure data were integrated across 4 double-blind, placebo-controlled studies of erenumab and their open-label extensions in patients with chronic or episodic migraine. Subgroup analyses were conducted by acute migraine-specific medication use and number of vascular risk factors at baseline. Standardized search terms were used to identify vascular AEs (cardiovascular, cerebrovascular, or peripheral). An independent committee adjudicated whether targeted events were vascular in origin.

\section{Results}

In placebo-controlled studies, 2,443 patients received placebo $(\mathrm{n}=1,043)$, erenumab $70 \mathrm{mg}$ ( $\mathrm{n}=893)$, or erenumab $140 \mathrm{mg}(\mathrm{n}=507)$ subcutaneously once monthly. Regardless of acute migraine-specific medication use or vascular risk factors at baseline, $\mathrm{AE}$ incidence was similar across the placebo and erenumab treatment groups. Hypertension AEs were reported for 0.9\% (placebo), $0.8 \%$ (erenumab $70 \mathrm{mg}$ ), and $0.2 \%$ (erenumab $140 \mathrm{mg}$ ) of patients. Vascular AEs, which were similar across double-blind and open-label treatment, generally were confounded, with plausible alternative etiologies. In 18 patients with events reviewed by the independent committee, 4 events were positively adjudicated as cardiovascular in origin: 2 deaths and 2 vascular events. All 4 positively adjudicated cardiovascular events occurred during open-label erenumab treatment.

\section{Conclusion}

Selective blockade of the canonical calcitonin gene-related peptide receptor with erenumab for migraine prevention had a vascular safety profile comparable to that of placebo over 12 weeks, with no increased emergence of events over time. Further study of long-term safety of erenumab in patients with migraine is needed.

\section{Clinicaltrials.gov identifiers}

NCT02066415, NCT02456740, NCT01952574, NCT02483585, NCT02174861, and NCT01723514.

\section{Classification of evidence}

This analysis provides Class II evidence that for patients with migraine, erenumab does not increase the risk of vascular AEs.

\section{Correspondence}

Dr. Kudrow

dbkudrow@earthlink.net

\section{MORE ONLINE}

$\rightarrow$ Class of Evidence

Criteria for rating

therapeutic and diagnostic studies

NPub.org/coe 


\section{Glossary}

AE = adverse event; ARISE = Study to Evaluate the Efficacy and Safety of Erenumab (AMG 334) Compared to Placebo in Migraine Prevention; $\mathbf{B P}=$ blood pressure; CGRP = calcitonin gene-related peptide; $\mathbf{D B P}=$ diastolic blood pressure; $\mathbf{S B P}=$ systolic blood pressure; MedDRA = Medical Dictionary for Regulatory Activities; NSAID = nonsteroidal anti-inflammatory drug; STRIVE = Study to Evaluate the Efficacy and Safety of Erenumab (AMG 334) in Migraine Prevention.

Migraine affects over 1 billion people worldwide $^{1}$ and $15 \%-20 \%$ of Americans. ${ }^{2}$ More than $25 \%$ of adults with migraine are candidates for preventive therapy, ${ }^{3}$ but fewer than $30 \%$ of candidates receive it. ${ }^{4,5}$ Over $80 \%$ of patients with chronic migraine discontinue oral preventive therapy within the first year. ${ }^{6}$ There is an unmet need for an effective, welltolerated therapy to prevent migraine.

Calcitonin gene-related peptide (CGRP) plays a key role in migraine pathophysiology. ${ }^{7,8}$ Monoclonal antibodies have recently been developed that bind to either CGRP or the canonical CGRP receptor to prevent migraine. Because CGRP can mediate vasodilation, ${ }^{9}$ inhibition of the CGRP pathway could theoretically attenuate compensatory vasodilation during ischemic conditions, but the relative importance of the CGRP receptor pathway compared with other vasodilatory pathways during ischemia (e.g., myocardial) has not been established. ${ }^{9-11}$ In addition, patients with migraine have an increased risk of vascular events, including stroke and myocardial ischemia, ${ }^{12,13}$ and acute migraine-specific medications such as triptans and ergotamine have known vasoconstrictive effects. ${ }^{14,15}$ Thus, it is important to examine vascular safety, particularly over the longer term, in patients treated with therapies that block the effects of CGRP.

Erenumab (in the United States, erenumab-aooe) is a fully human monoclonal antibody that specifically targets and blocks the canonical CGRP receptor to prevent migraine. ${ }^{16}$ Administered subcutaneously once monthly, erenumab has been shown to be effective for migraine prevention. ${ }^{17-20}$ This pooled analysis of vascular safety in clinical studies of erenumab for migraine prevention included vascular (cardiovascular, cerebrovascular, or peripheral) adverse events (AEs) that were reported by investigators, events that were adjudicated across all studies by an independent committee of clinical experts, and a pooled analysis of blood pressure (BP) measurements. This report also includes results of a 24-hour ambulatory BP monitoring study that assessed the potential cardiovascular effects of erenumab in healthy controls.

\section{Methods}

The primary research questions for this pooled analysis were to examine if the rates of vascular (cardiovascular or cerebrovascular) AEs were higher in the erenumab group vs the placebo group of controlled clinical studies, both overall and in subgroups of patients at a higher risk of vascular AEs, as well as the effect of erenumab treatment on BP. This analysis provides Class II evidence that for patients with migraine, erenumab does not increase the risk of vascular AEs.

\section{Design}

Information about AEs was collected as reported by the patient, either spontaneously or in response to the investigator's nondirected questioning, per standard procedures in clinical trials. Regulatory authorities in the regions where the trials were conducted reviewed study protocols, including $\mathrm{AE}$ data collection methods, before implementation. Reported AEs and $\mathrm{BP}$ results were integrated for 12 weeks of double-blind treatment across 4 placebo-controlled migraine prevention studies of erenumab administered subcutaneously once monthly. For long-term safety, $\mathrm{AE}$ data were integrated for any exposure to erenumab in these 4 studies and their openlabel extensions.

The pivotal studies testing the doses of erenumab that are approved for migraine prevention $(70 \mathrm{mg}$ and $140 \mathrm{mg}$ once monthly) were NCT02066415 ( $\mathrm{n}=667)$, which enrolled patients with chronic migraine, ${ }^{17}$ and NCT02456740 (Study to Evaluate the Efficacy and Safety of Erenumab [AMG 334] in Migraine Prevention [STRIVE]; $\mathrm{n}=955$ ), which enrolled patients with episodic migraine. ${ }^{18}$ The supportive studies NCT01952574 $(\mathrm{n}=483)^{19}$ and NCT02483585 (Study to Evaluate the Efficacy and Safety of Erenumab [AMG 334] Compared to Placebo in Migraine Prevention [ARISE]; $\mathrm{n}=$ $577)^{20}$ also enrolled patients with episodic migraine, but in the placebo-controlled periods of these studies, $70 \mathrm{mg}$ was the highest dose tested. Safety data for erenumab doses less than $70 \mathrm{mg}$, which were investigated in the placebo-controlled period of supportive study NCT01952574 but are not approved for migraine prevention, were excluded from this integrated safety analysis. All but 1 of the studies had a 12-week placebo-controlled period; the episodic migraine STRIVE study had a 24-week placebo-controlled period. Patients assigned to an erenumab arm received the same dose (70 or $140 \mathrm{mg}$ ) throughout double-blind treatment.

Patients completing the double-blind, placebo-controlled periods were continued in an active dose-blinded treatment period (STRIVE study) or open-label erenumab treatment (all other studies). For the episodic migraine studies, following completion of the double-blind placebo-controlled period, the active treatment or open-label treatment period was part of the main study protocol. In NCT01952574, open-label erenumab is being maintained for up to 256 weeks (5 years). ${ }^{21}$ Patients who completed the chronic migraine study could enter a separate open-label extension study (NCT02174861). 
During the active treatment or open-label periods, patients received only $70 \mathrm{mg}$ (ARISE study), or $70 \mathrm{mg}$ or $140 \mathrm{mg}$ (other studies).

Ambulatory BP was assessed in a phase 1 study (NCT01723514) that enrolled 32 healthy controls and 16 patients with migraine who received erenumab (70 or $140 \mathrm{mg}$ ) or placebo subcutaneously once monthly for 12 weeks. ${ }^{22}$

\section{Standard protocol approvals, registrations, and patient consents}

An institutional review board or independent ethics committee approved each study in this analysis. The studies included in this analysis were registered at clinicaltrials.gov: NCT02066415, NCT02456740, NCT01952574, NCT02483585, NCT02174861, and NCT01723514. Patients provided written informed consent to participate in each study.

\section{Eligibility criteria}

Each of the migraine prevention studies had an initial screening period (up to 3 weeks), followed by a 4-week, prospective baseline period to confirm study eligibility before the patient was enrolled and randomized. Key inclusion criteria at screening were age 18 years or older (up to 60 or 65 years) and a history of migraine with or without aura for at least 12 months. The chronic migraine study included patients with at least 15 headache days per month during the baseline period, of which at least 8 were migraine days. The episodic migraine studies included patients with fewer than 15 headache days per month during the baseline period, of which at least 4 were migraine days.

In the episodic migraine studies, use of medications for acute headache before screening was restricted as follows: acute migraine-specific medications (triptan or ergot) were limited to fewer than 10 days per month, analgesics or nonsteroidal anti-inflammatory drugs (NSAIDs) to fewer than 15 days per month, and opioids or butalbital-containing medications to fewer than 4 days per month. In the chronic migraine study, there was no restriction for prior use of acute migraine-specific medications, analgesics, or NSAIDs; however, in the prior 3 months, patients could not have used opioids on more than 12 days or butalbital on more than 6 days. In each migraine prevention study, after randomization, patients could use acute migraine-specific medications, analgesics, or NSAIDs as needed to treat acute migraine.

Patients were excluded from the migraine prevention studies if they had myocardial infarction, stroke, TIA, unstable angina, or coronary artery bypass surgery, or another revascularization procedure within 12 months prior to screening. Medically stable patients who had any of these listed conditions more than 12 months prior to screening could participate in the studies. Patients were excluded from studies NCT02066415 and NCT01952574 if they had poorly controlled hypertension (systolic BP [SBP] above
$150-160 \mathrm{~mm} \mathrm{Hg}$ or diastolic BP [DBP] above $90-100 \mathrm{~mm}$ $\mathrm{Hg}$ ), and patients with any unstable medical condition were excluded from each study. Healthy controls in the ambulatory BP study had no history of hypertension, hypotension, or vascular disease.

\section{Safety assessments}

AEs that were new or worsened after the first dose of study treatment were recorded through 12 weeks after the last dose in studies with doses up to $70 \mathrm{mg}$ (the ARISE study and study NCT01952574 before protocol amendment to include higher doses), and 16 weeks after the last dose in studies with doses up to $140 \mathrm{mg}$. For each AE, the Medical Dictionary for Regulatory Activities (MedDRA) was used to determine the preferred term and system organ class. AE severity was graded with Common Terminology Criteria for Adverse Events (CTCAE) criteria, version 4.03. A serious AE was defined as an $\mathrm{AE}$ that met at least 1 of the following criteria: fatal, lifethreatening, required inpatient hospitalization or prolongation of existing hospitalization, resulted in persistent or significant disability/incapacity, congenital anomaly/birth defect, or another medically important serious event.

Because of the acknowledged interest in the safety of this new class of medication, an independent committee was established to review potential vascular events. The adjudicators, who were clinical experts in cardiovascular and cerebrovascular disease, adjudicated each potential event based on prespecified definitions. Events that were referred to the adjudicators included the following: death, acute myocardial infarction or hospitalization for unstable angina event, nonfatal stroke or TIA, coronary revascularization procedure, hospitalization for hypertension, hospitalization for peripheral artery disease event, or revascularization procedure for peripheral artery disease. Adjudicators were blinded to treatment assignment throughout the adjudication process.

In each study, resting BP was measured at monthly study visits, before each administration of study treatment. The phase 1 study also monitored BP continuously for 24 hours, starting at 9:00 AM, on day -2 (i.e., 2 days before the first dose of study treatment) and on days 8,36 , and 64 (i.e., 7 days after each dose of study treatment).

\section{Statistical analysis}

Analyses of AEs were conducted for 2 pools of safety data. The "12-week placebo-controlled" pool was the integrated safety dataset from 12 weeks of double-blind treatment (or in the STRIVE study, the first 12 weeks of double-blind treatment). The "any erenumab exposure" pool included AEs that occurred during exposure to either double-blind or open-label erenumab treatment through the data cutoff for the 5-year open-label extension study (NCT01952574) or completion of the study (all other studies). Integrated analyses of AEs for the 12-week placebo-controlled pool were conducted by assigned treatment (placebo, erenumab $70 \mathrm{mg}$, or erenumab $140 \mathrm{mg}$ ). Integrated analyses for any erenumab exposure were 
summarized by actual treatment received (erenumab $70 \mathrm{mg}$ or erenumab $140 \mathrm{mg}$ ) when the AEs occurred. A single patient in the any erenumab exposure pool could have received both erenumab $70 \mathrm{mg}$ and $140 \mathrm{mg}$ because of the second randomization for the active treatment phase in the STRIVE study, or because of study protocol amendments in NCT02174861 and NCT01952574 that increased the openlabel dose of erenumab from $70 \mathrm{mg}$ to $140 \mathrm{mg}$ for all patients. If a patient experienced the same $\mathrm{AE}$ when he or she received each dose of erenumab, then this $\mathrm{AE}$ was counted for both $70 \mathrm{mg}$ and $140 \mathrm{mg}$. Exposure-adjusted incidence rates of AEs for any erenumab exposure pool were calculated by adjusting for the length of exposure to erenumab.

For the AE analyses in the 12-week placebo-controlled pool, 1 subgroup analysis examined the incidences of AEs separately by use or nonuse at baseline of acute migraine-specific medications (triptans or ergot). Another subgroup analysis examined the incidences of AEs separately by the number of vascular risk factors at baseline (none, 1 , or $\geq 2$ ) using 7 categories for vascular risk factors (table 1). Each subgroup analysis included incidences of any $\mathrm{AE}$, any $\mathrm{AE}$ by severity, any serious $\mathrm{AE}$, any $\mathrm{AE}$ leading to discontinuation of study treatment, and death.

To analyze vascular AEs, standardized MedDRA queries with narrow search terms were used to determine the overall incidences in each treatment group of the 12-week placebocontrol pool in the following categories: ischemic CNS vascular conditions, ischemic heart disease, peripheral arterial disease, or hypertension. The same queries were used to

Table 1 Determination of baseline vascular risk factors from reported data

\begin{tabular}{|c|c|}
\hline Category & Description \\
\hline Diabetes mellitus & History of diabetes mellitus \\
\hline Hypertension & $\begin{array}{l}\text { Medical history of hypertension or high } \\
\text { blood pressure at screening ( } \geq 2 \text { occasions } \\
\text { with systolic }>140 \mathrm{~mm} \mathrm{Hg} \text { or diastolic } \\
>90 \mathrm{~mm} \mathrm{Hg} \text { ) }\end{array}$ \\
\hline Obesity & Body mass index $>30 \mathrm{~kg} / \mathrm{m}^{2}$ \\
\hline Dyslipidemia & $\begin{array}{l}\text { Total cholesterol > } 200 \mathrm{mg} / \mathrm{dL} \text { or low-density } \\
\text { lipoprotein cholesterol >130 mg/dL or high- } \\
\text { density lipoprotein cholesterol < } 40 \mathrm{mg} / \mathrm{dL} \\
\text { or triglycerides }>150 \mathrm{mg} / \mathrm{dL} \text { or medical } \\
\text { history of dyslipidemia }\end{array}$ \\
\hline Cigarette use & History of smoking \\
\hline Coronary artery disease & $\begin{array}{l}\text { Ischemic heart disease (as reported in case } \\
\text { report forms for dedicated vascular } \\
\text { medical history or for general medical } \\
\text { history) }\end{array}$ \\
\hline $\begin{array}{l}\text { Cerebrovascular or } \\
\text { peripheral artery disease }\end{array}$ & $\begin{array}{l}\text { Cerebrovascular disease or peripheral } \\
\text { artery disease (as reported in case report } \\
\text { forms for dedicated vascular medical } \\
\text { history or for general medical history) or } \\
\text { medical history of peripheral } \\
\text { vasoconstriction, necrosis, or vascular } \\
\text { insufficiency }\end{array}$ \\
\hline
\end{tabular}

analyze vascular AEs for any erenumab exposure. The results of each search were summarized descriptively. Positively adjudicated vascular events were listed.

The integrated data analysis of the 12-week double-blind pool also summarized resting SBP and DBP at monthly study visits. To evaluate $\mathrm{BP}$ in a manner that was clinically relevant, the proportion of patients with an increase from baseline of $\geq 10 \mathrm{~mm} \mathrm{Hg}$ in DBP or $\geq 20 \mathrm{~mm} \mathrm{Hg}$ in SBP was evaluated at the monthly visits. For the phase 1 study of ambulatory BP, hourly SBP and DBP were summarized for each treatment group.

\section{Data availability}

Qualified researchers may request data from Amgen clinical studies. Complete details are available at amgen.com/ datasharing.

\section{Results}

\section{Patient disposition}

During 12 weeks of double-blind treatment across the $4 \mathrm{mi}-$ graine prevention studies, 2,443 patients with migraine received placebo $(n=1,043)$, erenumab $70 \mathrm{mg}(\mathrm{n}=893)$, or erenumab $140 \mathrm{mg}(\mathrm{n}=507)$. Most of these patients $(94 \%$ erenumab, $92 \%$ placebo) completed 12 weeks of double-blind treatment. In NCT01952574, an additional 213 patients who received lower doses of erenumab $7 \mathrm{mg}(\mathrm{n}=108)$ or $21 \mathrm{mg}(\mathrm{n}$ $=105$ ) were not included in the pooled safety analysis for 12 weeks of double-blind treatment but could be analyzed for AEs during any exposure to erenumab if they switched to $70 \mathrm{mg}$ for the open-label phase.

For the analysis of AEs during any exposure to erenumab, 2,499 patients received at least 1 dose of erenumab $70 \mathrm{mg}(\mathrm{n}$ $=2,128)$ or at least 1 dose of erenumab $140 \mathrm{mg}(\mathrm{n}=1,223)$. A single patient in any study except ARISE could have received both erenumab $70 \mathrm{mg}$ and $140 \mathrm{mg}$. Thus, considering all erenumab exposure during double-blind or open-label treatment, 852 patients received both doses of erenumab, 1,276 received only $70 \mathrm{mg}$, and 371 received only $140 \mathrm{mg}$. The total exposure to either dose of erenumab was 2,639 patient-years.

\section{Patient characteristics}

Baseline patient characteristics, use of acute migraine-specific medications, and vascular risk factors were balanced across the treatment groups (table 2). Upon entry into the respective study, mean patient age in each treatment group was 41.3-41.8 years, and $83.3 \%-85.0 \%$ of patients were female. Mean disease duration was approximately 21 years in each treatment group, and the mean number of monthly migraine days in each treatment group was 10.3-11.9. At baseline, acute migrainespecific medications were used by $64.1 \%-66.9 \%$ of patients in each treatment group. Almost all of the acute migraine-specific medications used were triptans ( $<1 \%$ were ergot-based). Medications for management of hypertension were used at baseline by $3.7 \%-6.5 \%$ of patients in each treatment group. 
Table 2 Patient demographic and clinical characteristics at baseline in 4 migraine prevention studies

\begin{tabular}{|c|c|c|c|}
\hline Baseline characteristic & $\begin{array}{l}\text { Placebo QM } \\
(n=1,043)\end{array}$ & $\begin{array}{l}\text { Erenumab } 70 \mathrm{mg} \mathrm{QM} \\
(\mathrm{n}=893)\end{array}$ & $\begin{array}{l}\text { Erenumab } 140 \mathrm{mg} \mathrm{QM} \\
(\mathrm{n}=507)\end{array}$ \\
\hline Age, y & $41.8 \pm 11.1$ & $41.7 \pm 11.2$ & $41.3 \pm 11.2$ \\
\hline Female & $869(83.3)$ & $755(84.5)$ & $431(85.0)$ \\
\hline White & $934(89.5)$ & $813(91.0)$ & $475(93.7)$ \\
\hline North America & $544(52.2)$ & $471(52.7)$ & $248(48.9)$ \\
\hline Body mass index, $\mathrm{kg} / \mathrm{m}^{2}$ & $26.8 \pm 5.8$ & $26.9 \pm 5.8$ & $26.7 \pm 6.0$ \\
\hline Disease duration, $y$ & $20.7 \pm 12.2$ & $20.8 \pm 12.4$ & $20.5 \pm 12.2$ \\
\hline History of migraine with aura & $481(46.1)$ & $429(48.0)$ & $231(45.6)$ \\
\hline History of migraine without aura & $925(88.7)$ & $788(88.2)$ & $450(88.8)$ \\
\hline Monthly migraine days & $11.1 \pm 5.5$ & $10.3 \pm 5.0$ & $11.9 \pm 5.8$ \\
\hline \multicolumn{4}{|l|}{ Acute headache medication use } \\
\hline Any & $1,024(98.2)$ & $872(97.6)$ & $498(98.2)$ \\
\hline Migraine-specific ${ }^{a}$ & $690(66.2)$ & $572(64.1)$ & $339(66.9)$ \\
\hline Non-migraine-specific & $822(78.8)$ & 705 (78.9) & $416(82.1)$ \\
\hline Any hypertension medication use & $68(6.5)$ & $33(3.7)$ & $22(4.3)$ \\
\hline History of vascular disorders & $77(7.4)$ & $59(6.6)$ & $50(9.9)$ \\
\hline \multicolumn{4}{|l|}{ No. of vascular risk factors } \\
\hline 0 & $310(29.7)$ & $233(26.1)$ & $148(29.2)$ \\
\hline 1 & $423(40.6)$ & $377(42.2)$ & $199(39.3)$ \\
\hline$\geq 2$ & $310(29.7)$ & $283(31.7)$ & $160(31.6)$ \\
\hline \multicolumn{4}{|l|}{ Vascular risk factors } \\
\hline High cholesterol level $^{\text {b }}$ & 489 (46.9) & $438(49.0)$ & $241(47.5)$ \\
\hline Obesityc & $253(24.3)$ & $230(25.8)$ & $133(26.2)$ \\
\hline High lipid level $^{\mathrm{d}}$ & $250(24.0)$ & $227(25.4)$ & $122(24.1)$ \\
\hline History of diabetes mellitus & $21(2.0)$ & $17(1.9)$ & $6(1.2)$ \\
\hline History of dyslipidemia & $93(8.9)$ & $69(7.7)$ & $31(6.1)$ \\
\hline History of hypertension & $93(8.9)$ & $51(5.7)$ & $34(6.7)$ \\
\hline High blood pressure at screening ${ }^{e}$ & $73(7.0)$ & $58(6.5)$ & $34(6.7)$ \\
\hline \multicolumn{4}{|l|}{ History of cigarette use } \\
\hline Current & $64(6.1)$ & $67(7.5)$ & $41(8.1)$ \\
\hline Former & $114(10.9)$ & $93(10.4)$ & $51(10.1)$ \\
\hline Never & $430(41.2)$ & 437 (48.9) & $227(44.8)$ \\
\hline Unknown & $435(41.7)$ & $296(33.1)$ & $188(37.1)$ \\
\hline
\end{tabular}

Abbreviation: $\mathrm{QM}=$ once monthly.

Data are presented as mean \pm SD or number (\%) of patients.

a Includes triptan-based or ergot-based medications ( $<1 \%$ received ergot-based medications).

${ }^{b}$ High cholesterol level is defined as one of the following: total cholesterol $>200 \mathrm{mg} / \mathrm{dL}$, low-density lipoprotein cholesterol >130 mg/dL, or high-density lipoprotein cholesterol $<40 \mathrm{mg} / \mathrm{dL}$.

c Obesity is defined as a body mass index $>30 \mathrm{~kg} / \mathrm{m}^{2}$.

${ }^{\mathrm{d}}$ High lipid level is defined as triglycerides $>150 \mathrm{mg} / \mathrm{dL}$.

e High blood pressure at screening is defined as systolic blood pressure $>140 \mathrm{~mm} \mathrm{Hg}$ or diastolic blood pressure $>90 \mathrm{~mm}$ Hg measured on at least 2 occasions. 
In each treatment group, 6.6\%-9.9\% of patients had a history of a vascular disorder, most commonly hypertension $(3.4 \%-5.1 \%)$. More than $70 \%$ of patients in each treatment group had at least 1 vascular risk factor at baseline (table 2). The most common vascular risk factor at baseline was dyslipidemia (based on high cholesterol, high lipids, or history of dyslipidemia). One in 4 patients was obese.

\section{Vascular adverse events in targeted searches}

In the targeted searches for vascular AEs during 12 weeks of double-blind treatment, investigators reported AEs of hypertension or diastolic hypertension for $9(0.9 \%)$ patients receiving placebo, $7(0.8 \%)$ receiving erenumab $70 \mathrm{mg}$, and $1(0.2 \%)$ receiving erenumab $140 \mathrm{mg}$ (table 3$)$. An $\mathrm{AE}$ of cerebral venous thrombosis was reported for $1(0.2 \%)$ patient in the erenumab $140 \mathrm{mg}$ group; review of the event did not suggest a causal association for erenumab. This female patient had multiple risk factors for venous thrombosis: age $\geq 40$ years, body mass index $>30 \mathrm{~kg} / \mathrm{m}^{2}$, a prior history of deep vein thrombosis and pulmonary embolism, recurrent heparin-induced thrombocytopenia, and a recent infection (sepsis, pyelonephritis, and kidney infection about 7 weeks before the event). No other ischemic vascular event was reported in any treatment group in the pooled 12-week placebo-controlled analysis.

In the targeted searches for vascular AEs during any erenumab exposure (either double-blind or open-label), the exposureadjusted patient incidence rate for an $\mathrm{AE}$ of hypertension was 2.5 per 100 patient-years for erenumab $70 \mathrm{mg}$ and 1.7 per 100 patient-years for erenumab $140 \mathrm{mg}$ (table 3). The exposureadjusted patient incidence rate for an $\mathrm{AE}$ of cerebral venous thrombosis was 0.2 per 100 patient-years for $140 \mathrm{mg}$, including the $\mathrm{AE}$ described above for the double-blind period and another $\mathrm{AE}$ during open-label erenumab treatment. The latter $\mathrm{AE}$ occurred in a 38-year-old man who experienced subdural hematoma, cerebral venous thrombosis, and facial bone fractures as a result of closed head injury sustained during a fall while hiking. He was found unconscious and under the influence of Ecstasy (3,4-methylenedioxy-methamphetamine). Two patients had an $\mathrm{AE}$ of myocardial ischemia $(<0.1$ per 100 patient-years for 70 $\mathrm{mg}$ ), both of which occurred during open-label erenumab treatment. One of these patients had demand ischemia that was a positively adjudicated vascular event (see description in the next section). The other patient had exercise-induced ischemia and had taken sumatriptan 4 hours before the exercise test. This patient received a total of 2 doses of erenumab $70 \mathrm{mg}$, with the second dose 36 days before the event. The dose of sumatriptan on the day of the event was $50 \mathrm{mg}$, and the patient's previous dose of sumatriptan was administered 68 days before the event. Other AEs in the searches for vascular events occurred in only 1 patient each. Review of the individual events did not suggest a causal association for erenumab.

\section{Adjudicated vascular events}

Eighteen patients had AEs that fulfilled criteria for adjudication. The blinded, independent, clinical experts adjudicated the events as cardiovascular in origin for 4 patients. All occurred during open-label erenumab treatment. For each adjudicated event, investigators considered the respective AEs as not related to erenumab treatment; adjudicators did not assess the relationship of positively adjudicated events to treatment. Details on these 4 events are given below.

A 55-year-old woman in the ARISE study had AEs of multifocal pneumococcal bacteremia, life-threatening acute respiratory distress syndrome, atrial fibrillation, myocardial (demand) ischemia, and elevated troponin levels on day 135, during open-label treatment with erenumab $70 \mathrm{mg}$.

A 54-year-old man in study NCT01952574 with a history of hypertensive cardiovascular disease died of arteriosclerosis and hypertensive heart disease on day 650 of exposure during openlabel treatment with erenumab $70 \mathrm{mg}$. On autopsy, there was evidence of severe coronary atherosclerosis with presence of alcohol and stimulants (phenylpropanolamine and norpseudoephedrine). This case was reported previously. ${ }^{21}$

A 44-year-old man in the STRIVE study with body mass index of $30 \mathrm{~kg} / \mathrm{m}^{2}$, high triglycerides, a history of abnormal ECG findings (first-degree atrioventricular block, intraventricular conduction defect, and anomalies of repolarization), and mild mitral prolapse died after 12 months of exposure to erenumab during open-label treatment with $140 \mathrm{mg}$. He was asymptomatic for the duration of the study, including during physical exertion. Postmortem genetic assessment revealed a genetic form of arrhythmogenic right ventricular cardiomyopathy/ dysplasia, which predisposes to sudden cardiac death. ${ }^{23}$ Consistent with this diagnosis, postmortem findings included hyperplastic sclerosis of coronary arteries, fat infiltration of the right heart chamber musculature, hypertrophy of the left cardiac musculature, and dilation of both cardiac chambers. The direct cause of death was attributed to heart failure.

A 64-year-old man in study NCT02174861 with a history of hypertension and migraine with aura had monocular visual blurring lasting 2 minutes on day 209 of exposure during open-label treatment with erenumab $140 \mathrm{mg}$ (10 weeks after last dose). The event was reported as an AE of TIA.

\section{AEs by use of acute migraine- specific medications}

Patients who used acute migraine-specific medications at baseline had similar incidences of AEs and serious AEs across the placebo and erenumab treatment groups (table 4). Overall, patients using acute migraine-specific medications had a slightly higher incidence of serious AEs compared with nonusers of acute migraine-specific medications. There was no evidence of an increased incidence of vascular AEs or serious vascular AEs among patients using acute migraine-specific medications.

\section{AEs by number of vascular risk factors at baseline}

Regardless of the number of vascular risk factors at baseline, incidences of AEs were similar across the placebo and 
Table 3 Treatment-emergent vascular adverse events in migraine prevention studies

\begin{tabular}{|c|c|c|c|c|c|}
\hline \multirow[b]{2}{*}{$\begin{array}{l}\text { Category } \\
\text { Preferred term }\end{array}$} & \multicolumn{3}{|c|}{ During 12 weeks of double-blind treatment } & \multicolumn{2}{|c|}{ During any exposure to erenumab } \\
\hline & $\begin{array}{l}\text { Placebo QM } \\
(n=1,043)\end{array}$ & $\begin{array}{l}\text { Erenumab } \\
70 \text { mg QM } \\
(n=893)\end{array}$ & $\begin{array}{l}\text { Erenumab } \\
140 \text { mg QM } \\
(n=507)\end{array}$ & $\begin{array}{l}70 \mathrm{mg} Q M \\
(n=2,128)\end{array}$ & $\begin{array}{l}140 \mathrm{mg} Q M \\
(\mathrm{n}=1,223)\end{array}$ \\
\hline Ischemic CNS vascular conditions & $0(0.0)$ & $0(0.0)$ & $1(0.2)$ & $\begin{array}{l}0(0.0) \\
2,068.2[0.0]\end{array}$ & $\begin{array}{l}4(0.3) \\
1,015.1[0.4]\end{array}$ \\
\hline Cerebral venous thrombosis & $0(0.0)$ & $0(0.0)$ & $1(0.2)$ & $\begin{array}{l}0(0.0) \\
2,068.2[0.0]\end{array}$ & $\begin{array}{l}2(0.2) \\
1,016.2[0.2]\end{array}$ \\
\hline Cerebrovascular disorder & $0(0.0)$ & $0(0.0)$ & $0(0.0)$ & $\begin{array}{l}0(0.0) \\
2,068.2[0.0]\end{array}$ & $\begin{array}{l}1(<0.1) \\
1,015.4[<0.1]\end{array}$ \\
\hline TIA $^{a}$ & $0(0.0)$ & $0(0.0)$ & $0(0.0)$ & $\begin{array}{l}0(0.0) \\
2,068.2[0.0]\end{array}$ & $\begin{array}{l}1(<0.1) \\
1,016.3[<0.1]\end{array}$ \\
\hline Ischemic heart disease & $0(0.0)$ & $0(0.0)$ & $0(0.0)$ & $\begin{array}{l}5(0.2) \\
2,066.2[0.2]\end{array}$ & $\begin{array}{l}0(0.0) \\
1,016.4[0.0]\end{array}$ \\
\hline Myocardial ischemia ${ }^{a}$ & $0(0.0)$ & $0(0.0)$ & $0(0.0)$ & $\begin{array}{l}2(<0.1) \\
2,067.5[<0.1]\end{array}$ & $\begin{array}{l}0(0.0) \\
1,016.4[0.0]\end{array}$ \\
\hline Angina pectoris & $0(0.0)$ & $0(0.0)$ & $0(0.0)$ & $\begin{array}{l}1(<0.1) \\
2,067.7[<0.1]\end{array}$ & $\begin{array}{l}0(0.0) \\
1,016.4[0.0]\end{array}$ \\
\hline Arteriosclerosis coronary artery & $0(0.0)$ & $0(0.0)$ & $0(0.0)$ & $\begin{array}{l}1(<0.1) \\
2,067.8[<0.1]\end{array}$ & $\begin{array}{l}0(0.0) \\
1,016.4[0.0]\end{array}$ \\
\hline Blood CPK-MB increased & $0(0.0)$ & $0(0.0)$ & $0(0.0)$ & $\begin{array}{l}1(<0.1) \\
2,067.8[<0.1]\end{array}$ & $\begin{array}{l}0(0.0) \\
1,016.4[0.0]\end{array}$ \\
\hline Peripheral arterial disease & $0(0.0)$ & $0(0.0)$ & $0(0.0)$ & $\begin{array}{l}1(<0.1) \\
2,067.9[<0.1]\end{array}$ & $\begin{array}{l}1(<0.1) \\
1,015.7[<0.1]\end{array}$ \\
\hline Raynaud phenomenon & $0(0.0)$ & $0(0.0)$ & $0(0.0)$ & $\begin{array}{l}1(<0.1) \\
2,067.9[<0.1]\end{array}$ & $\begin{array}{l}1(<0.1) \\
1,015.7[<0.1]\end{array}$ \\
\hline Hypertension & $9(0.9)$ & $7(0.8)$ & $1(0.2)$ & $\begin{array}{l}50(2.3) \\
2,034.8[2.5]\end{array}$ & $\begin{array}{l}17(1.4) \\
1,007.1[1.7]\end{array}$ \\
\hline Hypertension & $9(0.9)$ & $7(0.8)$ & $0(0.0)$ & $\begin{array}{l}41(1.9) \\
2,039.4[2.0]\end{array}$ & $\begin{array}{l}15(1.2) \\
1,008.9[1.5]\end{array}$ \\
\hline Diastolic hypertension & $0(0.0)$ & $0(0.0)$ & $1(0.2)$ & $\begin{array}{l}0(0.0) \\
2,068.2[0.0]\end{array}$ & $\begin{array}{l}1(<0.1) \\
1,015.1[<0.1]\end{array}$ \\
\hline Blood pressure increased & $0(0.0)$ & $0(0.0)$ & $0(0.0)$ & $\begin{array}{l}7(0.3) \\
2,063.8[0.3]\end{array}$ & $\begin{array}{l}1(<0.1) \\
1,015.9[<0.1]\end{array}$ \\
\hline Blood pressure diastolic increased & $0(0.0)$ & $0(0.0)$ & $0(0.0)$ & $\begin{array}{l}1(<0.1) \\
2,068.1[<0.1]\end{array}$ & $\begin{array}{l}0(0.0) \\
1,016.4[0.0]\end{array}$ \\
\hline Hypertensive heart disease ${ }^{a}$ & $0(0.0)$ & $0(0.0)$ & $0(0.0)$ & $\begin{array}{l}1(<0.1) \\
2,068.2[<0.1]\end{array}$ & $\begin{array}{l}0(0.0) \\
1,016.4[0.0]\end{array}$ \\
\hline
\end{tabular}

Abbreviations: CPK-MB = creatine phosphokinase-muscle/brain; QM = once monthly.

Data for double-blind treatment are presented as number (\%) of patients who received at least 1 dose of 70 mg or 1 dose of 140 mg (the same patient could have received both doses). Data for any exposure to erenumab are presented as number (\%) of patients/total time at risk in years [exposure-adjusted incidence rate per 100 patient-years], where total time at risk was the time from the patient's first dose of erenumab 70 mg or 140 mg to onset of the first event or, if no event occurred, to the earliest of patient's end of safety follow-up (12 or 16 weeks after last dose of $70 \mathrm{mg}$ or $140 \mathrm{mg}$, respectively), end of study, or data cutoff date. Each erenumab dose group includes adverse events while the patient received that dose. Multiple events of the same preferred term are only counted once per patient.

a Four patients had a positively adjudicated vascular event, including 1 patient each with a vascular adverse event of TIA, myocardial ischemia, and hypertensive heart disease, plus 1 patient without a reported vascular adverse event.

erenumab treatment groups (table 5). In the subgroup of patients with at least 2 vascular risk factors at baseline, there were slightly higher incidences of AEs or serious AEs compared with the subgroups of patients with no risk factor or 1 risk factor at baseline, but incidences were balanced across the placebo and erenumab groups. There was no evidence of an increased incidence of vascular AEs or serious vascular AEs among patients with vascular risk factors at baseline.

\section{Blood pressure changes}

In the integrated analysis of the 4 migraine prevention studies, resting $\mathrm{BP}$ readings were similar across the treatment groups and across the study visits (figure 1). Mean (SD) change in SBP from baseline to week 12 was $-0.4(9.6) \mathrm{mm} \mathrm{Hg}$ in the placebo group, $-0.5(10.0) \mathrm{mm} \mathrm{Hg}$ in the erenumab $70 \mathrm{mg}$ group, and $-1.0(9.8) \mathrm{mm} \mathrm{Hg}$ in the erenumab $140 \mathrm{mg}$ group. Mean (SD) change in DBP from baseline to week 12 was -0.6 
Table 4 Patient incidence of adverse events (AEs) during 12 weeks of double-blind treatment in 4 migraine prevention studies, by use of acute migraine-specific medications at baseline

\begin{tabular}{|c|c|c|c|c|c|c|}
\hline \multirow[b]{2}{*}{ AEs } & \multicolumn{3}{|c|}{ Users of acute migraine-specific medications } & \multicolumn{3}{|c|}{ Nonusers of acute migraine-specific medications } \\
\hline & $\begin{array}{l}\text { Placebo QM } \\
(\mathrm{N} 1=690)\end{array}$ & $\begin{array}{l}\text { Erenumab } 70 \mathrm{mg} \\
\mathrm{QM}(\mathrm{N} 1=572)\end{array}$ & $\begin{array}{l}\text { Erenumab } 140 \mathrm{mg} \\
\mathrm{QM}(\mathrm{N} 1=339)\end{array}$ & $\begin{array}{l}\text { Placebo QM } \\
\text { (N1 = 353) }\end{array}$ & $\begin{array}{l}\text { Erenumab } 70 \mathrm{mg} \\
\mathrm{QM}(\mathrm{N} 1=321)\end{array}$ & $\begin{array}{l}\text { Erenumab } 140 \mathrm{mg} \\
\mathrm{QM}(\mathrm{N} 1=168)\end{array}$ \\
\hline Any & $342(49.6)$ & $269(47.0)$ & $159(46.9)$ & $169(47.9)$ & $153(47.7)$ & $74(44.0)$ \\
\hline Any grade $\geq 2$ & $194(28.1)$ & $128(22.4)$ & $86(25.4)$ & 95 (26.9) & $89(27.7)$ & $37(22.0)$ \\
\hline Any grade $\geq 3$ & $24(3.5)$ & $21(3.7)$ & $9(2.7)$ & $9(2.5)$ & $9(2.8)$ & $7(4.2)$ \\
\hline Any grade $\geq 4$ & $0(0.0)$ & $1(0.2)$ & $0(0.0)$ & $0(0.0)$ & $0(0.0)$ & $1(0.6)$ \\
\hline Serious & $13(1.9)$ & $12(2.1)$ & $5(1.5)$ & $3(0.8)$ & $3(0.9)$ & $0(0.0)$ \\
\hline Discontinued $^{a}$ & $7(1.0)$ & $8(1.4)$ & $6(1.8)$ & $3(0.8)$ & $7(2.2)$ & $4(2.4)$ \\
\hline Death & $0(0.0)$ & $0(0.0)$ & $0(0.0)$ & $0(0.0)$ & $0(0.0)$ & $0(0.0)$ \\
\hline
\end{tabular}

Abbreviation: $\mathrm{QM}=$ once monthly.

Data are presented as number (\%) of patients. N1 is the number of patients with use/nonuse of an acute migraine-specific medication at baseline. Acute migraine-specific medications include triptan-based or ergot-based medications.

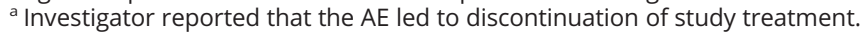

(7.1) $\mathrm{mm} \mathrm{Hg}$ in the placebo group, $-0.3(7.7) \mathrm{mm} \mathrm{Hg}$ in the erenumab $70 \mathrm{mg}$ group, and $-0.4(7.2) \mathrm{mm} \mathrm{Hg}$ in the erenumab $140 \mathrm{mg}$ group.

There were no clinically relevant differences across treatment groups for a SBP increase of $\geq 20 \mathrm{~mm} \mathrm{Hg}$ or a DBP increase of $\geq 10 \mathrm{~mm} \mathrm{Hg}$ from baseline at weeks 4, 8, and 12 (table 6).

In the 24-hour continuous BP monitoring study, SBP and DBP after 12 weeks of treatment in healthy controls were similar in the erenumab $70 \mathrm{mg}$ group and the erenumab $140 \mathrm{mg}$ group compared with the placebo group, and erenumab had no effect on the diurnal pattern of BP (figure 2). Similar results were observed for 24-hour continuous BP monitoring after the first and second monthly doses of placebo or erenumab in healthy controls, or after each dose of study treatment in patients with migraine (data not shown).

\section{Discussion}

During 12 weeks of double-blind treatment in 4 clinical studies of migraine prevention, the incidences of AEs were similar across the placebo, erenumab $70 \mathrm{mg}$, and erenumab $140 \mathrm{mg}$ groups, with no evidence of dose dependency for safety. Review of both individual and aggregate AEs did not find evidence of an association between erenumab treatment and vascular events, including cardiovascular, cerebrovascular,

Table 5 Patient incidence of adverse events (AEs) during 12 weeks of double-blind treatment in 4 migraine prevention studies, by number of vascular risk factors at baseline ${ }^{a}$

\begin{tabular}{|c|c|c|c|c|c|c|c|c|c|}
\hline \multirow[b]{2}{*}{ AEs } & \multicolumn{3}{|c|}{ No vascular risk factor } & \multicolumn{3}{|c|}{1 vascular risk factor } & \multicolumn{3}{|c|}{$\geq 2$ vascular risk factors } \\
\hline & $\begin{array}{l}\text { Placebo } \\
\text { QM } \\
(\mathrm{N} 1=310)\end{array}$ & $\begin{array}{l}\text { Erenumab } \\
70 \text { mg QM } \\
(\mathrm{N} 1=233)\end{array}$ & $\begin{array}{l}\text { Erenumab } \\
140 \text { mg QM } \\
(\mathrm{N} 1=148)\end{array}$ & $\begin{array}{l}\text { Placebo } \\
\text { QM } \\
(\text { N1 = 423) }\end{array}$ & $\begin{array}{l}\text { Erenumab } \\
70 \text { mg QM } \\
\text { (N1 = 377) }\end{array}$ & $\begin{array}{l}\text { Erenumab } \\
140 \text { mg QM } \\
(\mathrm{N} 1=199)\end{array}$ & $\begin{array}{l}\text { Placebo } \\
\text { QM } \\
(\text { N1 = 310) }\end{array}$ & $\begin{array}{l}\text { Erenumab } \\
70 \mathrm{mg} Q M \\
(\mathrm{~N} 1=283)\end{array}$ & $\begin{array}{l}\text { Erenumab } \\
140 \text { mg QM } \\
(\mathrm{N} 1=160)\end{array}$ \\
\hline Any & $147(47.4)$ & $111(47.6)$ & $58(39.2)$ & $196(46.3)$ & $174(46.2)$ & $87(43.7)$ & $168(54.2)$ & $137(48.4)$ & $88(55.0)$ \\
\hline Grade $\geq 2$ & $91(29.4)$ & $61(26.2)$ & $33(22.3)$ & $110(26.0)$ & $83(22.0)$ & $49(24.6)$ & $88(28.4)$ & $73(25.8)$ & $41(25.6)$ \\
\hline Grade $\geq 3$ & $10(3.2)$ & $7(3.0)$ & $4(2.7)$ & $12(2.8)$ & $12(3.2)$ & $5(2.5)$ & $11(3.5)$ & $11(3.9)$ & $7(4.4)$ \\
\hline Grade $\geq 4$ & $0(0.0)$ & $1(0.4)$ & $0(0.0)$ & $0(0.0)$ & $0(0.0)$ & $0(0.0)$ & $0(0.0)$ & $0(0.0)$ & $1(0.6)$ \\
\hline Serious & $3(1.0)$ & $2(0.9)$ & $2(1.4)$ & $7(1.7)$ & $6(1.6)$ & $1(0.5)$ & $6(1.9)$ & $7(2.5)$ & $2(1.3)$ \\
\hline Discontinued $^{b}$ & $4(1.3)$ & $8(3.4)$ & $3(2.0)$ & $4(0.9)$ & $6(1.6)$ & $4(2.0)$ & $2(0.6)$ & $1(0.4)$ & $3(1.9)$ \\
\hline Death & $0(0.0)$ & $0(0.0)$ & $0(0.0)$ & $0(0.0)$ & $0(0.0)$ & $0(0.0)$ & $0(0.0)$ & $0(0.0)$ & $0(0.0)$ \\
\hline
\end{tabular}

Abbreviation: QM = once monthly.

Data are presented as number (\%) of patients. N1 is the number of patients with that number of vascular risk factors at baseline.

a See table 1 for descriptions of the 7 categories of vascular risk factors.

${ }^{b}$ Investigator reported that the AE led to discontinuation of study treatment. 
Figure 1 Blood pressure by visit in patients with migraine during 12 weeks of double-blind treatment in 4 migraine prevention studies



or peripheral vascular events. Vascular ischemic events occurred during open-label erenumab treatment and were confounded with plausible alternative etiologies.

Subgroup analyses were conducted to examine the overall safety of erenumab in patients with migraine who might be at higher risk of vascular events. Approximately two-thirds of the patients were using an acute migraine-specific medication at baseline. Triptans and ergot-based medications have vasoconstrictive effects that may contribute to a higher risk of cardiovascular or cerebrovascular AEs with these acute medications. ${ }^{14,15}$ Thus, triptans and ergot-based medications have relative contraindications for use in patients at high risk of vascular events, which includes more than 900,000 men and women with migraine in the United States. ${ }^{24}$ In this analysis, the incidences of AEs were similar between the erenumab and placebo groups, supporting that adding erenumab to an acute migraine-specific medication did not increase risk compared with adding placebo to an acute migraine-specific medication. Overall, users of acute migrainespecific medications had a slightly higher incidence of serious AEs compared with nonusers of acute migraine-specific medications.

Among patients with common vascular risk factors at baseline, the incidences of AEs were similar across the placebo and erenumab treatment groups. Regardless of treatment group, the incidences of AEs and serious AEs were slightly higher in the subgroup of patients with at least 2 vascular risk factors than in those with 0 or 1 risk factor.

Erenumab treatment for 12 weeks also had no relevant effect on BP compared with placebo, either for resting measurements at monthly study visits in patients with episodic or chronic migraine, or for continuous 24-hour ambulatory BP monitoring after 12 weeks of treatment. There were no clinically relevant differences in the number of patients with a $\geq 10 \mathrm{~mm} \mathrm{Hg}$ increase in DBP or a $\geq 20 \mathrm{~mm} \mathrm{Hg}$ increase in SBP, no difference between erenumab and placebo for mean SBP or DBP, and no imbalances in outliers for BP. This is consistent with the similar incidence of clinically reported AEs of hypertension between the placebo and erenumab treatment groups during the first 12 weeks of the placebocontrolled studies, and a similar incidence of hypertension AEs during long-term erenumab treatment. Collectively, these analyses supported the vascular safety profile for erenumab across different study periods, populations, and methodologies, providing a comprehensive examination of the safety of erenumab treatment for migraine prevention.

Supportive information for these findings was provided by ex vivo studies that showed no vasoactive effect of erenumab 
Table 6 Percentage of patients by visit with increases from baseline in blood pressure during 12 weeks of double-blind treatment in 4 migraine prevention studies

\begin{tabular}{|c|c|c|c|}
\hline & $\begin{array}{l}\text { Placebo QM } \\
(n=1,043)\end{array}$ & $\begin{array}{l}\text { Erenumab } 70 \mathrm{mg} \text { QM } \\
(\mathrm{n}=893)\end{array}$ & $\begin{array}{l}\text { Erenumab } 140 \mathrm{mg} \mathrm{QM} \\
(\mathrm{n}=507)\end{array}$ \\
\hline \multicolumn{4}{|l|}{ Week 4} \\
\hline No. of patients with SBP/DBP result & 1,022 & 878 & 501 \\
\hline SBP increase $\geq 20 \mathrm{~mm} \mathrm{Hg}$ to $S B P \leq 140 \mathrm{~mm} \mathrm{Hg}$ & $15(1.5)$ & $14(1.6)$ & $8(1.6)$ \\
\hline SBP increase $\geq 20 \mathrm{~mm} \mathrm{Hg}$ to $S B P>140 \mathrm{~mm} \mathrm{Hg}$ & $9(0.9)$ & $6(0.7)$ & $3(0.6)$ \\
\hline DBP increase $\geq 10 \mathrm{~mm} \mathrm{Hg}$ to DBP $\leq 90 \mathrm{~mm} \mathrm{Hg}$ & $57(5.6)$ & $61(6.9)$ & $46(9.2)$ \\
\hline DBP increase $\geq 10 \mathrm{~mm} \mathrm{Hg}$ to $\mathrm{DBP}>90 \mathrm{~mm} \mathrm{Hg}$ & $10(1.0)$ & $19(2.2)$ & $2(0.4)$ \\
\hline \multicolumn{4}{|l|}{ Week 8} \\
\hline No. of patients with SBP/DBP result & 997 & 871 & 497 \\
\hline$S B P$ increase $\geq 20 \mathrm{~mm} \mathrm{Hg}$ to $S B P \leq 140 \mathrm{~mm} \mathrm{Hg}$ & $12(1.2)$ & $17(2.0)$ & $7(1.4)$ \\
\hline SBP increase $\geq 20 \mathrm{~mm} \mathrm{Hg}$ to $S B P>140 \mathrm{~mm} \mathrm{Hg}$ & $3(0.3)$ & $6(0.7)$ & $3(0.6)$ \\
\hline DBP increase $\geq 10 \mathrm{~mm} \mathrm{Hg}$ to $\mathrm{DBP} \leq 90 \mathrm{~mm} \mathrm{Hg}$ & $58(5.8)$ & $65(7.5)$ & $47(9.5)$ \\
\hline DBP increase $\geq 10 \mathrm{~mm} \mathrm{Hg}$ to $\mathrm{DBP}>90 \mathrm{~mm} \mathrm{Hg}$ & $15(1.5)$ & $12(1.4)$ & $2(0.4)$ \\
\hline \multicolumn{4}{|l|}{ Week 12} \\
\hline No. of patients with SBP/DBP result & 985 & 860 & 482 \\
\hline$S B P$ increase $\geq 20 \mathrm{~mm} \mathrm{Hg}$ to $S B P \leq 140 \mathrm{~mm} \mathrm{Hg}$ & $10(1.0)$ & $24(2.8)$ & $8(1.7)$ \\
\hline$S B P$ increase $\geq 20 \mathrm{~mm} \mathrm{Hg}$ to $S B P>140 \mathrm{~mm} \mathrm{Hg}$ & $8(0.8)$ & $8(0.9)$ & $4(0.8)$ \\
\hline DBP increase $\geq 10 \mathrm{~mm} \mathrm{Hg}$ to $\mathrm{DBP} \leq 90 \mathrm{~mm} \mathrm{Hg}$ & $70(7.1)$ & $67(7.8)$ & $44(9.1)$ \\
\hline DBP increase $\geq 10 \mathrm{~mm} \mathrm{Hg}$ to $\mathrm{DBP}>90 \mathrm{~mm} \mathrm{Hg}$ & $12(1.2)$ & $12(1.4)$ & $7(1.5)$ \\
\hline
\end{tabular}

Abbreviations: $\mathrm{DBP}=$ diastolic blood pressure; $\mathrm{QM}=$ once monthly; SBP = systolic blood pressure.

Data are presented as number (\%) of patients, except as specified.

beyond its blockade of the vasodilatory effect of CGRP. ${ }^{25,26}$ In those studies, which measured arterial segments from brain and coronary vessels, exposure to erenumab alone did not affect vascular contractility. Because erenumab is selective for the canonical CGRP receptor, the absence of an effect of erenumab on vascular tone may not be generalizable to other agents that block CGRP from binding to other receptors in the calcitonin-like receptor family or to the CGRP ligand itself. $^{27-29}$

Recent clinical studies provide additional support for the vascular safety of erenumab. An exercise treadmill safety study in 88 patients with coronary artery disease and stable angina showed no aggravation of myocardial ischemia in the patients who received erenumab compared with those who received placebo. ${ }^{30}$ Erenumab did not decrease exercise duration as measured by the change from baseline in total exercise time compared to placebo (the primary endpoint of the study). That study enrolled patients with coronary artery disease and stable angina; the study population was older (median age $\sim 65$ years) and contained a higher proportion of men $(78 \%)$ than this pooled analysis.
A drug-drug interaction study in 34 healthy controls found that concomitant administration of erenumab $140 \mathrm{mg}$ with the acute migraine-specific medication sumatriptan had no clinically meaningful or additive effects on resting BP compared with sumatriptan alone. ${ }^{22}$ Because the healthy controls in the latter study received sumatriptan, those with elevated BP or heart rate, a prolonged QT interval, or a history of major vascular event or major cardiovascular intervention were excluded from the study.

Strengths of this safety analysis in approximately 2,500 patients with migraine were the size and characteristics of the patient population and the overall extent of exposure to erenumab. Patient demographics (mostly female and mean age of approximately 40 years) were representative of patients with migraine, supporting the generalizability of the results to other patients with chronic or episodic migraine. Safety results from the individual studies were also consistent across patients with either chronic or episodic migraine. ${ }^{17-20}$ The number of patients was complemented by duration of exposure. The total exposure to erenumab was 2,639 patient-years, and one of the episodic migraine studies includes open-label 
Figure 2 Twenty-four-hour continuous blood pressure in healthy controls after 12 weeks of double-blind treatment in a phase 1 study

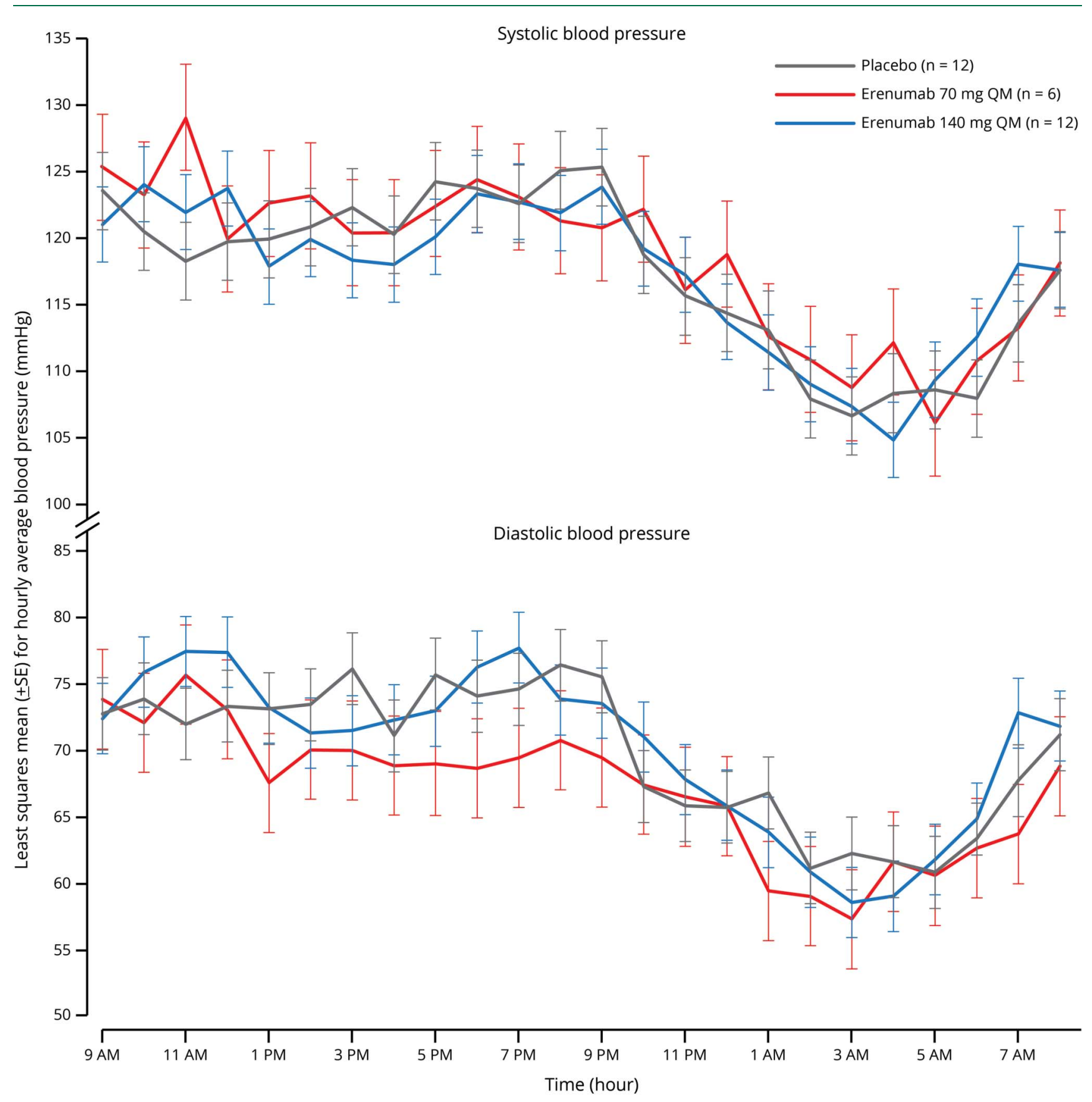

Assessment from day 64; patients received study treatment on days 1, 29, and 57.

treatment for up to 5 years. As noted above, the exclusion of patients with major vascular events within 12 months before each study was a limitation of the analysis, but this is typical for most studies of migraine treatment or prevention. In addition, patients with symptomatic vascular disease for more than 12 months before screening were allowed to participate in the erenumab studies of migraine prevention. Hypertension was not an exclusion criterion in the ARISE or STRIVE studies, and patients could participate in the other studies if they did not have poorly controlled hypertension. Thus, patients who might be excluded from many migraine prevention studies were allowed to enroll in the erenumab studies.

This safety analysis used data from the controlled setting of clinical trials. Additional safety data from real-world analyses would be useful to confirm the vascular safety of erenumab with widespread use in a broader patient population. A placebo comparator group was not available for the longer-term safety data in this analysis. A limitation of any open-label study 
is contextualization of events that occur when there is no comparator group. Assessment and adjudication of potential vascular ischemic events by a panel of clinical experts confirmed only 4 events as being vascular in origin. Each occurred during open-label erenumab treatment, when the adjudicators were not blinded to the patient's study treatment. While the independent adjudicators did not determine treatment relatedness, the investigators did not consider any of these events to be related to treatment. BP also seems to have been unaffected by erenumab treatment. If cardiovascular and cerebrovascular AEs do not occur more often, it might still be speculated that their severity is increased with blockade of the CGRP receptor. In these clinical studies, investigators were not specifically asked to judge whether the study treatment influenced the severity of vascular AEs. Given the rarity of these events (only 4 events in the whole dataset were deemed cardiovascular in origin), only substantial long-term real-world safety data will help address this question. Standardized searches for AE terms of vascular events used narrow search terms to increase specificity of the analyses. Sensitivity analyses using broad search terms identified 2 additional events that were not specific to vascular injury during any exposure to erenumab: T-wave inversion on ECG $(n=1)$ and increase in blood creatine phosphokinase $(n=17)$. Review of the individual AEs of increased blood creatine phosphokinase indicated that these were isolated events with no association with cardiac injury (most of them related to intense physical activity).

In this integrated analysis, erenumab had a vascular safety profile comparable to that of placebo over 12 weeks, and the overall safety profiles for erenumab and placebo were similar regardless of whether patients also used an acute migrainespecific medication or had risk factors for vascular events. A vascular safety signal did not emerge with longer-term treatment with dose-blinded or open-label erenumab for up to 256 weeks. Results from ex vivo studies and other clinical studies provided support for the vascular safety of erenumab treatment. Further study of long-term vascular safety of erenumab in patients with migraine is needed.

\section{Study funding}

This study was funded by Amgen Inc. and Novartis.

\section{Disclosure}

D. Kudrow has participated in advisory boards for Amgen, Novartis, Alder, Eli Lilly, Biohaven, and Promius; and has received research support from Amgen-Novartis, Alder, Teva, Eli Lilly, Biohaven, Zosano, Allergan, Roche-Genentech, Dr. Reddy's Laboratories, Novartis, and UCB. J. Pascual has received research support from Allergan and personal fees from Allergan, Stendhal, and Amgen-Novartis. P. Winner is an investigator in clinical trials sponsored by Teva, Amgen, Genentech, Novartis, Allergan, AstraZeneca, Biogen Idec, Ipsen, and Lilly; has participated in advisory boards for Teva, Amgen, Avanir, Novartis, Allergan, Supernus, and Lilly; and has been on speakers' bureaus for Allergan, Amgen, Avanir, Lilly, Promius, Novartis, and Supernus. D. Dodick has received personal fees from Amgen, Association of Translational Medicine, University Health Network, Daniel Edelman Inc., Autonomic Technologies, Axsome, Aural Analytics, Allergan, Alder, Biohaven, Charleston Laboratories, Dr. Reddy's Laboratories/Promius, Electrocore LLC, Eli Lilly, eNeura, Neurolief, Novartis, Ipsen, Impel, Satsuma, Supernus, Sun Pharma (India), Theranica, Teva, Vedanta, WL Gore, Nocira, PSL Group Services, University of British Columbia, Zosano, ZP Opco, Foresite Capital, and Oppenheimer; has received CME fees or royalty payments from Healthlogix, Medicom Worldwide, Medlogix Communications, Mednet, Miller Medical, PeerView, WebMD Health/Medscape, Chameleon, Academy for Continued Healthcare Learning, Universal Meeting Management, Haymarket, Global Scientific Communications, Global Life Sciences, Global Access Meetings, UpToDate (Elsevier), Oxford University Press, Cambridge University Press, and Wolters Kluwer Health; has stock options for Aural analytics, Healint, Theranica, Second Opinion/Mobile Health, Epien, GBS/Nocira, Matterhorn/ Ontologics, and King-Devick Technologies; has been a consultant without fee for Aural Analytics, Healint, Second Opinion/Mobile Health, and Epien; has a board of directors position for Epien, Matterhorn/Ontologics, and King-Devick Technologies; has a patent without a fee (Botulinum Toxin Dosage Regimen for Chronic Migraine Prophylaxis); has received professional society fees or reimbursement for travel from American Academy of Neurology, American Brain Foundation, American Headache Society, American Migraine Foundation, International Headache Society, and Canadian Headache Society; and has a use agreement through employer for Myndshft. S. Tepper has received research support (no personal compensation) from Alder, Allergan, Amgen, ATI, Dr. Reddy's, ElectroCore, eNeura, Neurolief, Scion Neurostim, Teva, and Zosano; is a consultant for Acorda, Alder, Alexsa, Allergan, Alphasights, Amgen, ATI, Axsome Therapeutics, Biohaven, Charleston Labs, DeepBench, Dr. Reddy's, ElectroCore, Eli Lilly, eNeura, GLG, Guidepoint Global, GSK, M3 Global Research, Magellan Rx Management, Medicxi, Navigant Consulting, Neurolief, Nordic BioTech, Novartis, Pfizer, Reckner Healthcare, Relevale, Satsuma, Scion Neurostim, Slingshot Insights, Sorrento, Sudler and Hennessey, Supernus, Teva, Theranica, Trinity Partners, XOC, and Zosano; holds stock options from ATI; receives royalties from Springer; and receives a salary from Dartmouth-Hitchcock Medical Center and the American Headache Society. U. Reuter has received personal fees from Amgen, Alder, Allergan, Autonomic Technologies, Eli Lilly, ElectroCore, Medscape, Novartis, StreaMedUp, and Teva. F. Hong is an employee and stockholder of Novartis. J. Klatt is an employee and stockholder of Novartis. F. Zhang is an employee and stockholder of Amgen Inc. S. Cheng is an employee and stockholder of Amgen Inc. H. Picard is an employee and stockholder of Amgen Inc. O. Eisele is an employee and stockholder of Amgen Inc. J. Wang is an employee and stockholder of Amgen Inc. J. Latham received personal fees from Amgen Inc. for medical writing support. D. Mikol is an employee and stockholder of Amgen Inc. Go to Neurology.org/N for full disclosures. 


\section{Publication history}

Received by Neurology December 4, 2018. Accepted in final form August 6, 2019.

Appendix Authors

\begin{tabular}{|c|c|c|c|}
\hline Name & Location & Role & Contribution \\
\hline $\begin{array}{l}\text { David } \\
\text { Kudrow, } \\
\text { MD }\end{array}$ & $\begin{array}{l}\text { California Medical } \\
\text { Clinic for Headache, } \\
\text { Santa Monica }\end{array}$ & Author & $\begin{array}{l}\text { Major role in the } \\
\text { acquisition of data, } \\
\text { interpreted the data, } \\
\text { revised the manuscript } \\
\text { for intellectual content }\end{array}$ \\
\hline
\end{tabular}

\begin{tabular}{llll}
\hline $\begin{array}{l}\text { Julio } \\
\text { Pascual, } \\
\text { MD, PhD }\end{array}$ & $\begin{array}{l}\text { Department of } \\
\text { Neurology and IDIVAL, } \\
\text { University Hospital } \\
\text { Marqués de Valdecilla, } \\
\text { Santander, Spain }\end{array}$ & Author & $\begin{array}{l}\text { Major role in the } \\
\text { acquisition of data, } \\
\text { interpreted the data, } \\
\text { revised the manuscript } \\
\text { for intellectual content }\end{array}$ \\
\hline $\begin{array}{l}\text { Paul K. } \\
\text { Winner, } \\
\text { DO }\end{array}$ & $\begin{array}{l}\text { Premiere Research } \\
\text { Institute, Nova } \\
\text { Southeastern } \\
\text { University, West Palm } \\
\text { Beach, FL }\end{array}$ & Author & $\begin{array}{l}\text { Major role in the } \\
\text { acquisition of data, } \\
\text { interpreted the data, } \\
\text { revised the manuscript } \\
\text { for intellectual content }\end{array}$ \\
\hline
\end{tabular}

\begin{tabular}{ll}
\hline David W. & Department of \\
Dodick, & Neurology, Mayo \\
MD & Clinic, Phoenix, AZ
\end{tabular}

Author Major role in the acquisition of data, interpreted the data, revised the manuscript for intellectual content

\begin{tabular}{llll}
\hline $\begin{array}{l}\text { Stewart J. } \\
\text { Tepper, } \\
\text { MD, FAHS }\end{array}$ & $\begin{array}{l}\text { Department of } \\
\text { Neurology, Geisel } \\
\text { School of Medicine at } \\
\text { Dartmouth, Hanover, } \\
\text { NH }\end{array}$ & Author & $\begin{array}{l}\text { Major role in the } \\
\text { acquisition of data, } \\
\text { interpreted the data, } \\
\text { revised the manuscript } \\
\text { for intellectual content }\end{array}$ \\
\hline $\begin{array}{l}\text { Uwe } \\
\text { Reuter, } \\
\text { MD }\end{array}$ & $\begin{array}{l}\text { Department of } \\
\text { Neurology, Charite } \\
\text { Universitätsmedizin } \\
\text { Berlin, Germany }\end{array}$ & Author & $\begin{array}{l}\text { Major role in the } \\
\text { acquisition of data, } \\
\text { interpreted the data, } \\
\text { revised the manuscript } \\
\text { for intellectual content }\end{array}$
\end{tabular}

\begin{tabular}{llll}
\hline $\begin{array}{l}\text { Frank } \\
\text { Hong, } \\
\text { MD, PhD }\end{array}$ & $\begin{array}{l}\text { Novartis, East } \\
\text { Hanover, NJ }\end{array}$ & Author & $\begin{array}{l}\text { Interpreted the data, } \\
\text { revised the manuscript } \\
\text { for intellectual content }\end{array}$ \\
\hline $\begin{array}{l}\text { Jan Klatt, } \\
\text { MD }\end{array}$ & $\begin{array}{l}\text { Novartis, Basel, } \\
\text { Switzerland }\end{array}$ & Author & $\begin{array}{l}\text { Interpreted the data, } \\
\text { revised the manuscript } \\
\text { for intellectual content }\end{array}$
\end{tabular}

\begin{tabular}{lll}
\hline $\begin{array}{l}\text { Feng } \\
\text { Zhang, Amgen Inc., Thousand }\end{array}$ Author & $\begin{array}{l}\text { Analyzed the data, } \\
\text { interpreted the data, } \\
\text { MS }\end{array}$ \\
& & drafted the manuscript \\
& for intellectual content, \\
& revised the manuscript \\
& for intellectual content
\end{tabular}

Sunfa Amgen Inc., Thousand Author Interpreted the data,

Cheng, Oaks, CA drafted the manuscript MD for intellectual content, revised the manuscript for intellectual content

\begin{tabular}{llll}
\hline $\begin{array}{l}\text { Hernan } \\
\text { Picard, } \\
\text { MD, PhD }\end{array}$ & $\begin{array}{l}\text { Amgen Inc., Thousand } \\
\text { Oaks, CA }\end{array}$ & Author & $\begin{array}{l}\text { Interpreted the data, } \\
\text { drafted the manuscript } \\
\text { for intellectual content, } \\
\text { revised the manuscript } \\
\text { for intellectual content }\end{array}$ \\
\hline $\begin{array}{l}\text { Osa } \\
\text { Eisele, }\end{array}$ & Amgen Inc., Thousand & Author & $\begin{array}{l}\text { Interpreted the data, } \\
\text { drafted the manuscript } \\
\text { MD, MPH }\end{array}$ \\
& & $\begin{array}{l}\text { for intellectual content, } \\
\text { revised the manuscript } \\
\text { for intellectual content }\end{array}$
\end{tabular}

Appendix (continued)

\begin{tabular}{|c|c|c|c|}
\hline Name & Location & Role & Contribution \\
\hline $\begin{array}{l}\text { Julie } \\
\text { Wang, } \\
\text { DPM }\end{array}$ & $\begin{array}{l}\text { Amgen Inc., Thousand } \\
\text { Oaks, CA }\end{array}$ & Author & $\begin{array}{l}\text { Drafted the manuscript } \\
\text { for intellectual content, } \\
\text { revised the manuscript } \\
\text { for intellectual content }\end{array}$ \\
\hline $\begin{array}{l}\text { Jonathan } \\
\text { N. } \\
\text { Latham, } \\
\text { PharmD }\end{array}$ & $\begin{array}{l}\text { PharmaScribe, LLC, } \\
\text { Atlanta, GA }\end{array}$ & Author & $\begin{array}{l}\text { Drafted the manuscript } \\
\text { for intellectual content, } \\
\text { revised the manuscript } \\
\text { for intellectual content }\end{array}$ \\
\hline $\begin{array}{l}\text { Daniel D. } \\
\text { Mikol, } \\
\text { MD, PhD }\end{array}$ & $\begin{array}{l}\text { Amgen Inc., Thousand } \\
\text { Oaks, CA }\end{array}$ & Author & $\begin{array}{l}\text { Analyzed the data, } \\
\text { interpreted the data, } \\
\text { drafted the manuscript } \\
\text { for intellectual content, } \\
\text { revised the manuscript } \\
\text { for intellectual content }\end{array}$ \\
\hline
\end{tabular}

\section{References}

1. GBD 2016 Headache Collaborators. Global, regional, and national burden of migraine and tension-type headache, 1990-2016: a systematic analysis for the Global Burden of Disease Study 2016. Lancet Neurol 2018;17:954-976.

2. US Burden of Disease Collaborators, Mokdad AH, Ballestros K, et al. The state of US health, 1990-2016: burden of diseases, injuries, and risk factors among US States. JAMA 2018;319:1444-1472.

3. Lipton RB, Bigal ME, Diamond M, Freitag F, Reed ML, Stewart WF. Migraine prevalence, disease burden, and the need for preventive therapy. Neurology 2007;68: 343-349.

4. Diamond S, Bigal ME, Silberstein S, Loder E, Reed M, Lipton RB. Patterns of diagnosis and acute and preventive treatment for migraine in the United States: results from the American Migraine Prevalence and Prevention Study. Headache 2007;47: 355-363.

5. Blumenfeld AM, Bloudek LM, Becker WJ, et al. Patterns of use and reasons for discontinuation of prophylactic medications for episodic migraine and chronic migraine: results from the second International Burden of Migraine Study (IBMS-II). Headache 2013;53:644-655.

6. Hepp Z, Dodick DW, Varon SF, Gillard P, Hansen RN, Devine EB. Adherence to oral migraine-preventive medications among patients with chronic migraine. Cephalalgia 2015;35:478-488.

7. Ho TW, Edvinsson L, Goadsby PJ. CGRP and its receptors provide new insights into migraine pathophysiology. Nat Rev Neurol 2010;6:573-582.

8. Edvinsson L, Haanes KA, Warfvinge K, Krause DN. CGRP as the target of new migraine therapies-successful translation from bench to clinic. Nat Rev Neurol 2018; 14:338-350.

9. Russell FA, King R, Smillie SJ, Kodji X, Brain SD. Calcitonin gene-related peptide: physiology and pathophysiology. Physiol Rev 2014;94:1099-1142.

10. MaassenVanDenBrink A, Terwindt GM, van den Maagdenberg AMJM. Calcitonin gene-related peptide (receptor) antibodies: an exciting avenue for migraine treatment. Genome Med 2018;10:10.

11. Kurth T, Winter AC, Eliassen AH, et al. Migraine and risk of cardiovascular disease in women: prospective cohort study. BMJ 2016;353:i2610.

12. Murinova N, Krashin DL, Lucas S. Vascular risk in migraineurs: interaction of endothelial and cortical excitability factors. Headache 2014;54:583-590.

13. Mahmoud AN, Mentias A, Elgendy AY, et al. Migraine and the risk of cardiovascular and cerebrovascular events: a meta-analysis of 16 cohort studies including 1152407 subjects. BMJ Open 2018;8:e020498.

14. Wackenfors A, Jarvius M, Ingemansson R, Edvinsson L, Malmsjö M. Triptans induce vasoconstriction of human arteries and veins from the thoracic wall. J Cardiovasc Pharmacol 2005;45:476-484.

15. Silberstein SD. The pharmacology of ergotamine and dihydroergotamine. Headache 1997;37(suppl 1):S15-S25.

16. Shi L, Lehto SG, Zhu DX, et al. Pharmacologic characterization of AMG 334, a potent and selective human monoclonal antibody against the calcitonin gene-related peptide receptor. J Pharmacol Exp Ther 2016;356:223-231.

17. Tepper S, Ashina M, Reuter U, et al. Safety and efficacy of erenumab for preventive treatment of chronic migraine: a randomised, double-blind, placebo-controlled phase 2 trial. Lancet Neurol 2017;16:425-434.

18. Goadsby PJ, Reuter U, Hallström Y, et al. A controlled trial of erenumab for episodic migraine. N Engl J Med 2017;377:2123-2132.

19. Sun H, Dodick DW, Silberstein S, et al. Safety and efficacy of AMG 334 for prevention of episodic migraine: a randomised, double-blind, placebo-controlled, phase 2 trial. Lancet Neurol 2016;15:382-390.

20. Dodick DW, Ashina M, Brandes JL, et al. ARISE: a phase 3 randomized trial of erenumab for episodic migraine. Cephalalgia 2018;38:1026-1037. 
21. Ashina M, Dodick D, Goadsby PJ, et al. Erenumab (AMG 334) in episodic migraine: interim analysis of an ongoing open-label study. Neurology 2017;89: 1237-1243.

22. de Hoon J, Van Hecken A, Vandermeulen C, et al. Phase I, randomized, double-blind, placebo-controlled, single-dose, and multiple-dose studies of erenumab in healthy subjects and patients with migraine. Clin Pharmacol Ther 2018;103:815-825.

23. Corrado D, Link MS, Calkins H. Arrhythmogenic right ventricular cardiomyopathy N Engl J Med 2017;376:61-72.

24. Lipton RB, Reed ML, Kurth T, Fanning KM, Buse DC. Framingham-based cardiovascular risk estimates among people with episodic migraine in the US population: results from the American Migraine Prevalence and Prevention (AMPP) study. Headache 2017;57:1507-1521.

25. Ohlsson L, Haanes K, Kronvall E, Xu C, Snellman J, Edvinsson L. Erenumab (AMG 334), a monoclonal antagonist antibody against the canonical CGRP receptor, does not impair vasodilatory or contractile responses to other vasoactive agents in human isolated cranial arteries. Epub 2019 Jul 31.

26. Beltrán AER, Ramírez AL, Bogers AJ, et al. Pharmacological selectivity of inhibition of CGRP-induced relaxations by erenumab studied in human isolated internal mammary artery (abstract MTIS2018-041). Cephalalgia 2018;38:30.

27. Poyner D. Pharmacology of receptors for calcitonin gene-related peptide and amylin. Trends Pharmacol Sci 1995; 16:424-428.

28. Walker CS, Hay DL. CGRP in the trigeminovascular system: a role for CGRP, adrenomedullin and amylin receptors? Br J Pharmacol 2013;170:1293-1307.

29. Walker CS, Eftekhari S, Bower RL, et al. A second trigeminal CGRP receptor: function and expression of the AMY1 receptor. Ann Clin Transl Neurol 2015;2:595-608.

30. Depre C, Antalik L, Starling A, et al. A randomized, double-blind, placebo-controlled study to evaluate the effect of erenumab on exercise time during a treadmill test in patients with stable angina. Headache 2018;58:715-723. 


\title{
Neurology
}

\author{
Vascular safety of erenumab for migraine prevention \\ David Kudrow, Julio Pascual, Paul K. Winner, et al. \\ Neurology 2020;94;e497-e510 Published Online before print December 18, 2019 \\ DOI 10.1212/WNL.0000000000008743
}

This information is current as of December 18, 2019

Updated Information \&
Services
References
Citations
Subspecialty Collections

Errata

Permissions \& Licensing

Reprints including high resolution figures, can be found at: http://n.neurology.org/content/94/5/e497.full

This article cites 29 articles, 5 of which you can access for free at: http://n.neurology.org/content/94/5/e497.full\#ref-list-1

This article has been cited by 2 HighWire-hosted articles: http://n.neurology.org/content/94/5/e497.full\#\#otherarticles

This article, along with others on similar topics, appears in the following collection(s):

Migraine

http://n.neurology.org/cgi/collection/migraine

Patient safety

http://n.neurology.org/cgi/collection/patient_safety

An erratum has been published regarding this article. Please see next page or:

/content/94/23/1052.2.full.pdf

Information about reproducing this article in parts (figures,tables) or in its entirety can be found online at:

http://www.neurology.org/about/about_the_journal\#permissions

Information about ordering reprints can be found online:

http://n.neurology.org/subscribers/advertise

Neurology $\mathbb{B}$ is the official journal of the American Academy of Neurology. Published continuously since 1951, it is now a weekly with 48 issues per year. Copyright Copyright (C) 2019 The Author(s). Published by Wolters Kluwer Health, Inc. on behalf of the American Academy of Neurology.. All rights reserved. Print ISSN: 0028-3878. Online ISSN: 1526-632X.

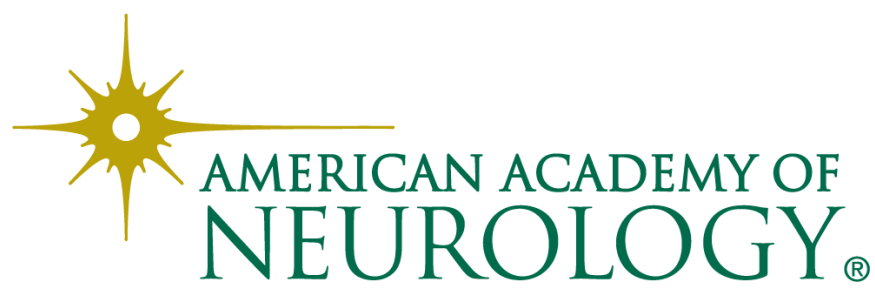




\title{
Disputes \& Debates: Editors' Choice
}

Steven Galetta, MD, FAAN, Section Editor

\section{Editors' note: Epidemiology of NMOSD in Sweden from 1987 to 2013: A nationwide population-based study}

In their retrospective observational cohort study of 294 patients with neuromyelitis optica spectrum disorder (NMOSD), Drs. Jonsson et al. summarized the rising incidence rate of this condition in Sweden between 1987 and 2013. The investigators postulate that the higher incidence rate- 0.79 per $1,000,000$ person-years from 0.30 per $1,000,000$ personyears - may have been attributed, in part, to heightened awareness of the disease and greater availability of MRI and NMO antibody testing. These incidence estimates mirror what have been reported in other predominantly Caucasian cohorts. In response, Drs. Papp et al. reiterate that although incidence and prevalence estimates are similar between nations of similar ethnic profiles, Southern Denmark has reported some of the highest prevalence (4.4 per 100,000 person-years) and incidence rates (4.0 per 1,000,000 person-years). Drs. Jonsson et al. comment that the higher estimates reported by Asgari et al. from Southern Denmark may be partially explained by the prospective nature of their study and the fact that patients from that study were evaluated for NMOSD even if optic neuritis was the presenting symptom. Based on the collective results from these studies, it is likely that NMOSD remains an underrecognized condition, and physicians should have a lower threshold to evaluate these patients with serum antibody testing and MRI, given the treatment considerations that are specific to NMOSD compared with MS. A correction to figure 5 was published in the September 10, 2019, issue of Neurology.

James E. Siegler III, MD, and Steven Galetta, MD

Neurology ${ }^{\circledR}$ 2020;94:1048. doi:10.1212/WNL.0000000000009598

\section{Reader response: Epidemiology of NMOSD in Sweden from 1987 to 2013: A nationwide population-based study}

\begin{abstract}
Viktoria Papp (Odense, Denmark), Thor Petersen (Aarhus, Denmark), Melinda Magyari (Copenhagen), Nils Koch-Henriksen (Aarhus, Denmark), Jette Lautrup Frederiksen (Glostrup, Denmark),

Finn Sellebjerg (Copenhagen), Egon Stenager (Odense, Denmark), and Zsolt Illes (Odense, Denmark) Neurology ${ }^{\circledR}$ 2020;94:1048-1049. doi:10.1212/WNL.0000000000009602
\end{abstract}

We read the nationwide Swedish epidemiologic study of neuromyelitis optica spectrum disorder (NMOSD) published by Jonsson et al. ${ }^{1}$ with great interest. The study revealed similar prevalence (1.04 per 100,000 people [CI: $0.85-1.26])$ and incidence $(0.79$ per $1,000,000$ person-years [CI: $0.55-1.03])$ of NMOSD to the prevalence $(1.09$ per 100,000 people [CI: $0.81-1.44])$ and incidence (0.70 per 1,000,000 person-years [CI: 0.46-1.02]) estimates of the recent nationwide Danish study ${ }^{2}$ and also to the incidence study of NMOSD from the Region of Central Denmark (incidence: 0.12 per 1,000,000 person-years). ${ }^{3}$ These studies from Scandinavia showed similar data to each other and also to other white populations, and they contrast with the results of the study from the region of Southern Denmark, ${ }^{4}$ reporting the highest prevalence (4.4 per 100,000 people [CI: 3.1-5.7]) and incidence (4.0 per 1,000,000 person-years [CI: 3.0-5.4]) so far in a predominantly Caucasian population. 
We would also like to bring attention to figure 5 (Comparison of incidence and prevalence in Sweden with other regions) concerning the incidence estimates. ${ }^{1}$ The incidence of NMOSD in Australia and New Zealand published by Bukhari et al. ${ }^{5}$ is 0.37 per $1,000,000$ person-years (CI: $0.35-0.39$ ) and not 3.7 per 1,000,000 person-years (CI: 3.5-3.9), as it is incorrectly shown in figure 5 .

1. Jonsson DI, Sveinsson O, Hakim R, et al. Epidemiology of NMOSD in Sweden from 1987 to 2013: a nationwide population-based study. Neurology 2019;93:e181-e189.

2. Papp V, Illes Z, Magyari M, et al. Nationwide prevalence and incidence study of neuromyelitis optica spectrum disorder in Denmark. Neurology 2018;91:e2265-e2275.

3. Dale GH, Svendsen KB, Gjelstrup MC, et al. Incidence of neuromyelitis optica spectrum disorder in the Central Denmark Region. Acta Neurol Scand 2018;137:582-588.

4. Asgari N, Lillevang ST, Skejoe HP, et al. A population-based study of neuromyelitis optica in Caucasians. Neurology 2011;76: 1589-1595.

5. Bukhari W, Prain KM, Waters P, et al. Incidence and prevalence of NMOSD in Australia and New Zealand. J Neurol Neurosurg Psychiatry 2017;88:632-638.

Copyright @ 2020 American Academy of Neurology

\section{Author response: Epidemiology of NMOSD in Sweden from 1987 to 2013: A nationwide population-based study}

Dagur I. Jonsson (Stockholm), Olafur Sveinsson (Stockholm), Ramil Hakim (Stockholm), and

Lou Brundin (Stockholm)

Neurology ${ }^{\circledR}$ 2020;94:1049-1050. doi:10.1212/WNL.0000000000009601

We are grateful for the comments on our article ${ }^{1}$ from our Danish colleagues who recently conducted a similar study ${ }^{2}$ applying comparable methods. These studies were conducted in parallel, and independent from each other, in ethnically similar populations, strengthening the results of both studies. The study by Asgari ${ }^{3}$ in 2011 was conducted differently, and data were collected prospectively and involved ophthalmology departments in the Southern Denmark region. Importantly, the study by Asgari implied that there may be an undetected population of patients with neuromyelitis optica spectrum disorder (NMOSD) with optic neuritis as an onset symptom, which is missed. This could partly account for the differing results. Also, Papp et al. correctly pointed out that in figure 5 of our article, ${ }^{1}$ we mistakenly reported the incidence of NMOSD in Australia and New Zealand ${ }^{4}$ as 3.7 per 1,000,000 person-years (CI: 3.5-3.9). The correct incidence is 0.37 per $1,000,000$ person-years (CI: $0.35-0.39)$. We are sorry for the mistake and thankful for the correction. The corrected figure does not in any way change the conclusions put forward in our article. 


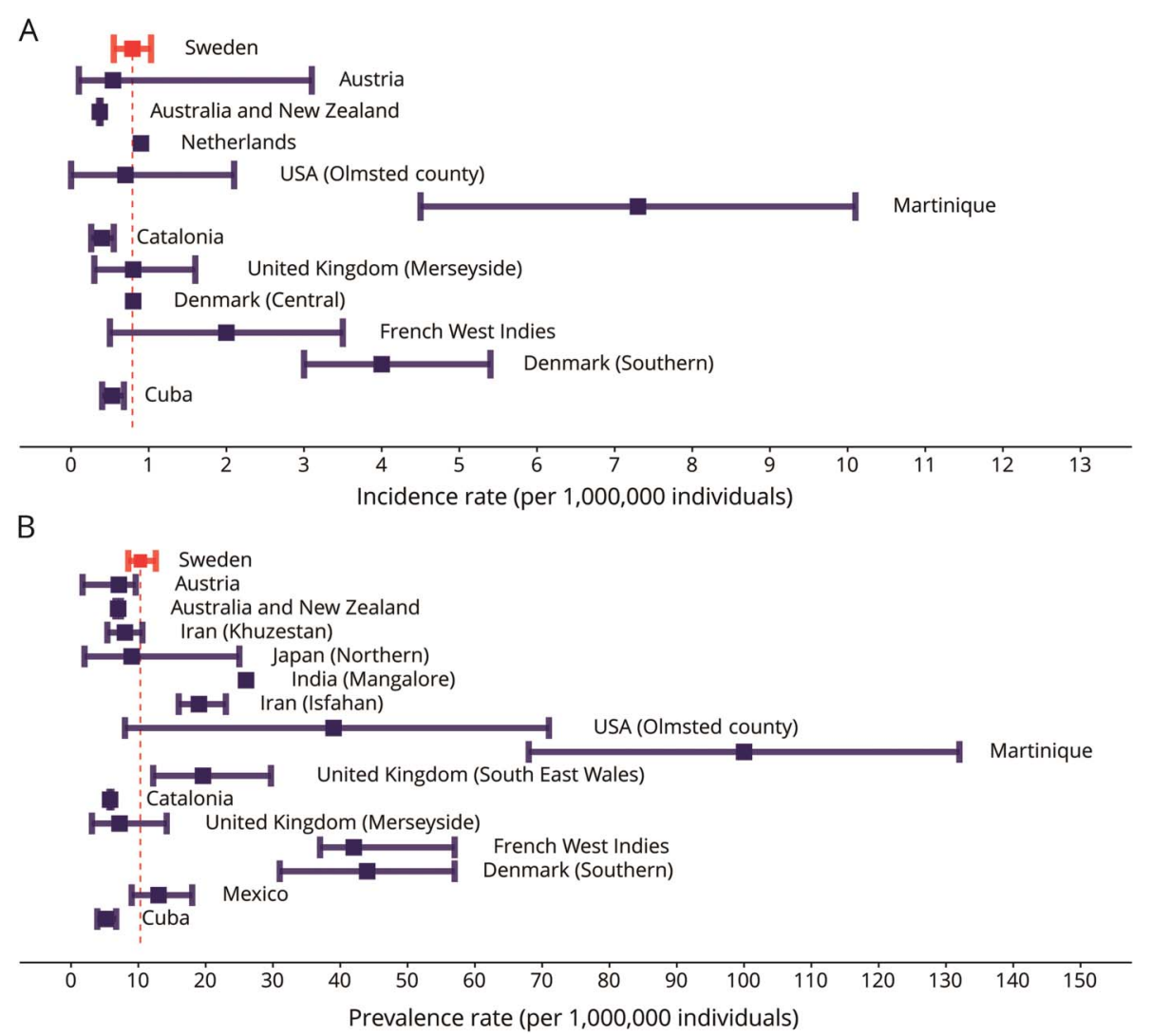

Incidence (A) and prevalence (B) of neuromyelitis optica/neuromyelitis optica spectrum disorder in other regions from available publications. Horizontal error bars represent the mean surrounded by a $95 \% \mathrm{Cl}$.

1. Jonsson DI, Sveinsson O, Hakim R, Brundin L. Epidemiology of NMOSD in Sweden from 1987 to 2013: a nationwide population-based study. Neurology 2019;93:e181-e189.

2. Papp V, Illes Z, Magyari M, et al. Nationwide prevalence and incidence study of neuromyelitis optica spectrum disorder in Denmark. Neurology 2018;91:e2265-e2275

3. Asgari N, Lillevang ST, Skejoe HP, et al. A population-based study of neuromyelitis optica in Caucasians. Neurology 2011;76 1589-1595.

4. Bukhari W, Prain KM, Waters P, et al. Incidence and prevalence of NMOSD in Australia and New Zealand. J Neurol Neurosurg Psychiatry 2017;88:632-638.

Copyright @ 2020 American Academy of Neurology 


\section{Editors' note: Low hemoglobin and hematoma expansion after intracerebral hemorrhage}

To corroborate previous reports that lower hemoglobin levels may be associated with hematoma expansion (HE) and poor functional outcomes after intracerebral hemorrhage (ICH), Drs. Roh et al. queried their single-center prospective ICH registry of 256 patients. After adjustment for known predictors of HE, each $1 \mathrm{~g} / \mathrm{dL}$ fall in hemoglobin levels was associated with a $20 \%$ higher odds of $\mathrm{HE}$ and $24 \%$ higher odds of severe disability (modified Rankin Scale score 4-6) at 3 months. Mediation analysis demonstrated that HE contributed to the poor long-term outcomes seen in patients with lower admission hemoglobin levels. Yu et al. address important unmeasured confounders-notably, coagulopathy - which could have also contributed to adverse radiographic and clinical outcomes. However, as Dr. Roh responds, patients in this study were excluded if there was evidence of coagulopathy secondary to systemic disease. Furthermore, the investigators adjusted for the use of therapeutic anticoagulation, irrespective of coagulation studies. Ultimately, both groups agree that these results warrant replication in further studies.

James E. Siegler III, MD, and Steven Galetta, MD

Neurology ${ }^{\circledR}$ 2020;94:1051. doi:10.1212/WNL.0000000000009604

\section{Reader response: Low hemoglobin and hematoma expansion after intracerebral hemorrhage}

Zhiyuan Yu (Chengdu, China), Jun Zheng (Chengdu, China), and Chao You (Chengdu, China) Neurology ${ }^{\circledR}$ 2020;94:1051. doi:10.1212/WNL.0000000000009607

With interest and appreciation, I read the article by Roh et al., ${ }^{1}$ which suggested that low hemoglobin levels could be related to hematoma expansion in intracerebral hemorrhage. Although previous studies have shown anemia is associated with worse outcomes in these patients, ${ }^{2,3}$ the study by Roh et al. is the first one showing that hematoma expansion mediates this association. However, some issues should be noted.

The time from onset to baseline CT was relatively long (median 5.6 hours), which could influence the identification of hematoma expansion. Moreover, some important results of laboratory coagulation testing, such as prothrombin time and international normalized ratio, were not included in multivariate logistic regression, which could make the results not robust enough. Therefore, their findings still need to be confirmed by further studies.

1. Roh DJ, Albers DJ, Magid-Bernstein J, et al. Low hemoglobin and hematoma expansion after intracerebral hemorrhage. Neurology 2019;93:e372-e380.

2. Kuramatsu JB, Gerner ST, Lücking H, et al. Anemia is an independent prognostic factor in intracerebral hemorrhage: an observational cohort study. Crit Care 2013;17:R148.

3. Zhang S, Pan X, Wei C, et al. Associations of anemia with outcomes in patients with spontaneous intracerebral hemorrhage: a metaanalysis. Front Neurol 2019;10:406.

Copyright @ 2020 American Academy of Neurology 


\section{Author response: Low hemoglobin and hematoma expansion after intracerebral hemorrhage}

David J. Roh (New York)

Neurology ${ }^{\circledR}$ 2020;94:1052. doi:10.1212/WNL.0000000000009608

The comments posited by Yu et al. ${ }^{1}$ appropriately highlight limitations of single-center observational data and the importance of external replication for our findings. While adjusting for laboratory coagulation testing is important to consider, it is worth noting that we excluded patients with laboratory evidence of coagulopathy because of systemic medical disease. In addition, we adjusted for anticoagulation use, which should account for prothrombin time/ international normalized ratio elevations due to a medication effect. Subsequently, it would be unlikely that the addition of laboratory coagulation markers in a multivariable model would affect the conclusions seen in our cohort.

If our findings are replicated, the need to study the mechanism(s) behind the findings is important. Given that underlying medical illness can be associated with lower hemoglobin levels, it is plausible that the relationship of lower hemoglobin levels with hematoma expansion and poor outcomes seen in our cohort is driven by the underlying disease rather than the hemoglobin level itself. Translational studies may be the only way to disentangle this potentially confounding factor; it is important to consider this factor before advocating for liberal red blood cell transfusion in intracerebral hemorrhage, as there are known complications associated with unnecessary red blood cell transfusions.

1. Roh DJ, Albers DJ, Magid-Bernstein J, et al. Low hemoglobin and hematoma expansion after intracerebral hemorrhage. Neurology 2019;93:e372-e380.

Copyright @ 2020 American Academy of Neurology

\section{CORRECTION}

\section{Vascular safety of erenumab for migraine prevention}

Neurology ${ }^{\circledR}$ 2020;94:1052. doi:10.1212/WNL.0000000000009310

In the article "Vascular safety of erenumab for migraine prevention" by Kudrow et al., ${ }^{1}$ Dr. Pascual's affiliation should have been listed as the University of Cantabria. The authors regret the error.

\section{Reference}

1. Kudrow D, Pascual J, Winner PK, et al. Vascular safety of erenumab for migraine prevention. Neurology 2020;94:e497-e510. 